\title{
IDENTIFIKASI \\ PROGRAM \\ PENGENTASAN \\ KEMISKINAN DI KELURAHAN MALABRO \\ KECAMATAN TELUK SEGARA KOTA BENGKULU \\ MENGGUNAKAN MODEL CENTER OF ISLAMIC BUSINESS AND EKONOMIC STUDIES (CIBEST)
}

\author{
Nilda Susilawati \\ IAIN Bengkulu \\ nilda@gmail.com
}

\begin{abstract}
This study aims to identify poverty alleviation programs in the Malabro village in the Sagara Bay of Bengkulu as a sample of poverty alleviation programs in the city of Bengkulu. This research is a qualitative research combined with the analysis of the CIBEST model. The results of this study found that $95.26 \%$ of families are materially poor and spiritually rich and 4.74 families are materially rich and spiritually rich. While the poverty alleviation program is carried out with the distribution of consumptive zakat funds, distribution of productive long-term zakat funds, working capital assistance for poor households, scholarship assistance for poor children, entrepreneurship motivation training and increased business competitiveness for youth youth groups, empowering fishermen wives through training in processing fish catches, and home garden land use through hydroponic training.
\end{abstract}

Keywords: Poverty, CIBEST, Sagara Bay, Spiritual

\begin{abstract}
Abstrak. Penelitian ini bertujuan Untuk mengidentifikasi program pengentasan kemiskinan pada kelurahan Malabro di Teluk Sagara Bengkulu sebagai sample dari program pengentasan kemiskinan di kota Bengkulu. Penelitian ini merupakan penelitian Kualitatif dikombinasikan dengan analisa model CIBEST. Hasil penelitian ini menemukan bahwa 95,26\% keluarga miskin materi dan kaya spiritual dan 4,74 keluarga kaya materi dan kaya spiritual. Sedangkan program pengentasan kemiskinan dilakukan dengan Penyaluran dana zakat konsumtif, Penyaluran dana zakat produktif yang bersifat jangka panjang, bantuan modal kerja untuk rumahtangga miskin, bantuan beasiswa bagi anak anak miskin, Pelatihan motivasi kewirausahaan dan peningkatan daya saing usaha bagi pemuda karang taruna, pemberdayaan istri nelayan melalui pelatihan pengolahan hasil tangkapan ikan, dan pemanfaatan lahan pekarangan rumah melalui pelatihan hidroponik.
\end{abstract}

Kata Kunci: Kemiskinan, CIBEST, Teluk Sagara, Spiritual 


\section{Pendahuluan}

Kebanyakan di negara yang sedang berkembang kondisi pembangunan negara masih belum stabil dan sustainable, sehingga menimbulkan berbagai masalah makroekonomi seperti kemiskinan. Banyak faktor yang meyebabkan terjadinya kemiskinan seperti faktor individual, sosial, kultural, dan struktural. ${ }^{1}$ Namun apapun itu penyebabnya, kemiskinan membawa banyak dampak negatif terhadap kehidupan masyarakat suatu negara baik secara materiil maupun secara spritual. Secara materiil kemiskinan akan memperlemah daya beli masyarakat dalam memenuhi kebutuhan yang mendasar seperti makanan, pakaian, perumahan, pendidikan, kesehatan. ${ }^{2}$ Kemiskinan materiil akan membuat seseorang kehilangan kelogisan berfikir, kehilangan akhlak yang baik sehingga mampu melakukan berbagai tindak kejahatan yang pada akhirnya akan membuat mereka juga miskin secara spritual karena melupakan Allah Swt dan rasa sosialnya kepada sesama. ${ }^{3}$

Begitu banyak dampak negatif yang ditimbulkan dari kemiskinan maka perlu bagi kita untuk memikirkan upaya pengentasan kemiskinan materiil maupun spritual. Salah satu model yang dapat digunakan untuk pengetasan kemiskinan materiil dan spritual adalah model Center of Islamic Business and Ekonomic Studies (CIBEST ). ${ }^{4}$ Model CIBEST merupakan salah satu model yang dapat digunakan untuk pengentasan kemiskinan materiil dan spritual melalui pemetaan kondisi rumah tangga, mengelompokan kemiskinan kedalam kemiskinan materiil dan spritual sehingga dapat diusulkan program pengentasan kemiskinan yang tepat. Model ini pernah diterapkan oleh Beik yang meneliti tentang, "Konsep Islamic Poverty Line”, IPB. Hasil penelitian menemukan bahwa kemiskinan terdiri dari kemiskinan materiil, spiritual dan kemiskinan absolute sehingga dapat dibentuk suatu kuadran yang disebut kuadran CIBEST.

Indonesia termasuk salah satu negara berkembang yang juga menghadapi masalah kemiskinan. Berdasarkan data Badan Pusat Statistik (BPS), jumlah penduduk miskin di Indonesia pada Maret 2017 adalah 27,77 juta orang (10,64\%), naik 6,90 ribu orang dibandingkan dengan penduduk miskin pada September 2016 sebanyak 27,76 juta orang $(10,70 \%)^{5}$. Data ini menggambarkan bahwa kondisi kemiskinan di Indonesia cukup memprihatinkan.

Bengkulu merupakan salah satu provinsi di Indonesia memiliki tingkat kemiskinan tertinggi di pulau Sumatera. Menurut data BPS periode September 2015, Bengkulu menjadi provinsi dengan jumlah penduduk miskin terbesar di

\footnotetext{
${ }^{1}$ Irfan Syauqi Beik dan Laily Dwi Arsyianti, Ekonomi Pembangunan ..., h.70

${ }^{2}$ Irfan Syauqi Beik dan Laily Dwi Arsyianti, Ekonomi Pembangunan ..., h. 78

${ }^{3}$ Nurul Huda dkk, Ekonomi pembangunan..., h.24

${ }^{4}$ Irfan Syauqi Beik dan Laily Dwi Arsyianti, Ekonomi Pembangunan ..., h 80

${ }^{5}$ Badan Pusat Statistik. September 2017. Laporan Bulanan Data Sosial Ekonomi, Edisi 88.https://www.bps.go.id/website/pdf_publikasi/Laporan-Bulanan-Data-Sosial-Ekonomi. , diakses 21 September 2017. Jam 17.30 WIB.
} 
pulau Sumatera yaitu 17,22 \% yang mengalami peningkatan dibanding tahun 2014 dengan jumlah penduduk miskin sebesar 17,09 \%.

Persentase terbesar rumahtangga miskin di Kota Bengkulu berada di Kecamatan Teluk Segara sebesar 31,96\%, dengan Malabro sebagai kelurahan dengan angka kemiskinan tertinggi ${ }^{6}$. Kemiskinan yang terjadi dikelurahan Malabro harus mendapatkan perhatian dan penanganan yang serius terutama dari pemerintah Kota Bengkulu. Dengan merencanakan berbagai program yang efektif sehingga dapat memperbaiki kondisi kemiskinan di daerah ini. Penelitian ini mencoba membantu pemerintah Kota Bengkulu untuk memetakan, mengelompokan kondisi kemiskinan serta mencoba mengidentifikasi program pengentasan kemiskinan di Kelurahan Malabro Kecamatan Teluk Segara Kota Bengkulu dengan menggunakan model CIBEST.

Informan penelitian terdiri atas :

a. Kepala bidang (Kabid) Sosial Badan Pusat Statistik (BPS) Provinsi Bengkulu

b. Camat Kecamatan Teluk Segara Kota Bengkulu

c. Lurah Malabro Kecamatan Teluk Segara Kota Bengkulu

d. Kabag Administrasi Baznas Kota Bengkulu

e. Seluruh rumahtangga muslim yang ada di Kelurahan Malabro Kecamatan Teluk Segara Kota Bengkulu, sebagai informan kunci.

Pemilihan rumahtangga muslim sebagai populasi didasarkan pada penggunaan indikator kebutuhan spritual yang mengacu kepada sholat, puasa, zakat dan infak, yang hanya dilakukan oleh seorang muslim.

Kelurahan Malabro memiliki 2507 penduduk dengan jumlah kepala keluarga sebanyak $502 \mathrm{KK}$, yang tersebar di 12 RT. Dari RT 01 sampai Rt 10 didiami mayoritas penduduk muslim, sementara RT 11 dan 12 merupakan rumah tangga dengan mayoritas etnis tionghoa. Sehingga yang dijadikan sampel teoritis hanya penduduk RT 01 sd RT 10 sebanyak $418 \mathrm{KK}^{7}$

Jika jumlah populasi kurang dari 100 maka semua populasi menjadi sampel, namun bila lebih dari 100 maka bisa diambil $10 \%$ sd $25 \%$ sebagai sampel. Maka untuk informan kunci sampel teoritis ditentukan $10 \%$ x $418 \mathrm{KK}$ $=41,8$ (dibulatkan menjadi 42) keluarga atau rumahtangga. Informan kunci dipilih dengan teknik snowball.

\section{Kemiskinan}

Kemiskinan diartikan sebagai keadaan masyarakat dengan tingkat ekonominya masih lemah, ${ }^{8}$ sehingga tidak mampu memenuhi kebutuhan

\footnotetext{
${ }^{6}$ Hasil wawancara dengan Sri Hartati, Kasi Kessos Kecamatan Teluk Segara Kota Bengkulu, 18 Mei 2017, jam 10.00 WIB

${ }^{7}$ Data sekunder Kelurahan Malabro Kecamatan Teluk Segara Kota Bengkulu, 19 Mei 2017, jam 09.00 WIB

${ }^{8}$ Subandi, Ekonomi Pembangunan, ( Bandung, Afabeta, 2014), h. 77
} 
hidupnya. ${ }^{9}$ Dalam konteks Indonesia, Badan Pusat Statistik (BPS) menggunakan konsep kemampuan memenuhi kebutuhan dasar makanan dan bukan makanan sebagai dasar pengukuran kemiskinan, dimana kebutuhan dasar makanan dihitung dengan pendekatan kalori minimal setara dengan $2100 \mathrm{kkal}$, sedangkan kebutuhan dasar bukan makanan dihitung berdasarkan konsumsi sejumlah komoditas bukan makanan. ${ }^{10}$

Dalam sudut pandang yang lebih sempit, kemiskinan itu dipahami sebagai suatu keadaan ketidakmampuan memenuhi kebutuhan konsumsi dasar. Lalu, dalam perspektif yang lebih luasnya, kemiskinan itu mengandung unsurunsur sosial dan moralitas. Tidak heran bila kita menjumpai pendapat yang mengatakan bahwa kemiskinan timbul karena adanya ketidakadilan dalam pemilikan faktor produksi; bahwa kemiskinan terkait dengan sikap, budaya hidup, dan lingkungan dalam suatu masyarakat; atau bahwa kemiskinan adalah ketidakberdayaan sekelompok masyarakat berhadapan dengan sistem yang diterapkan oleh suatu pemerintah. Akibatnya, posisi mereka menjadi sangat lemah dan tereksploitasi. ${ }^{11}$

Mengacu pada dua perspektif tersebut sembari berkaca pada realita, kita pun dapat secara gamblang menyimpulkan bahwa kemiskinan bukan sekedar ketidakmampuan dalam memenuhi kebutuhan dasar, melainkan berkaitan erat dengan berbagai dimensi kehidupan manusia seperti jaminan kesehatan, pendidikan, masa depan dan peranan sosial. Artinya, kita dapat memahami secara utuh mengenai kemiskinan manakala kita melihat dimensi-dimensi kehiduupan yang lainnya. ${ }^{12}$

Dimensi-dimensi kemiskinan itu meliputi: ketidakmampuan memenuhi kebutuhan dasar, tidak adanya/kurangnya akses terhadap kebutuhan dasar lainnya seperti pendidikan, kesehatan, air bersih, sanitasi, maupun transportasi; kerentanan terhadap goncangan yang bersifat individual maupun massal; rendahnya kualitas sumber daya manusia dan terbatasnya sumber daya alam; tidak adanya jaminan masa depan akibat rendahnya investasi pendidikan keluarga; tidak adanya/kurangnya akses terhadap lapangan pekerjaan dan mata pencahrian yang berkelanjutan, ketidakberdayaan akibat adanya cacat fisik dan mental; serta ketidakmampuan dan ketidakberuntungan sosial seperti anak-anak terlantas, wanita akibat kekerasan dalam rumah tangga, janda miskin atau karena merupakan kelompok marjinal dan terpencil. ${ }^{13}$

Gambaran kemiskinan dapat dilihat sebagai kelaparan, ketiadaan tempat berteduh, ketidakmampuan mendapatakan pengobatan secara medis, ketiadaan akses untuk bersekolah dan buta huruf, pengangguran, kekhawatiran tentang

\footnotetext{
${ }^{9}$ Irfan Syauqi Beik dan Laily Dwi Arsyianti, Ekonomi Pembangunan Syariah, (Jakarta: Raja Grafindo Perada, 2016), h.68

${ }^{10}$ Irfan Syauqi Beik dan Laily Dwi Arsyianti, Ekonomi Pembangunan ..., h.69

11 Bernhard Limbong, Ekonomi Kerakyatan dan nasionalisme Ekonomi, Jakarta: margharetha Pustaka) h. 205

${ }^{12}$ Bernhard Limbong, Ekonomi Kerakyatan dan nasionalisme..., h. 206

${ }^{13}$ Bernhard Limbong, Ekonomi Kerakyatan dan nasionalisme..., h. 206
} 
masa depan bahkan kehidupan pada suatu hal berikutnya. Potret kemiskinan lainnya adalah kehidupan yang tidak sehat yang disebabkan oleh air yang kotor, ketidakberdayaan, kehilangan aspirasi dan kebebasan. Kemiskinan yang dipahami memiliki konsep multidimensional mencakup seluruh indikator kesejahteraan, mempunyai banyak wajah, yang berubah dari waktu ke waktu, dari satu tempat ke tempat yang lain. ${ }^{14}$

Kekurangmampuan tersebut mungkin hanya pada tingkat kebutuhankebutuhan budaya (adat, upacara-upacara, moral dan etika), atau pada tingkat pemenuhan kebutuhan-kebutuhan sosial (pendidikan, berkomunikasi dan berinteraksi dengan sesama) atau pada tingkat pemenuhan kebutuhankebutuhan yang mendasar (makan-minum, berpakaian, bertempat tinggal atau rumah, kesehatan dan sebagainya). Kemiskinan terserap ke dalam dan menpengaruhi hampir keseluruhan aspek-aspek kehidupan manusia. Kemiskinan yang diderita oleh sekelompok orang bahkan sebuah masyarakat, menghasilkan suatu keadaan dimana warga masyarakat yang bersangkutan merasa tidak miskin bila berada dan hidup diantara sesamanya. Karena berbagai kegiatan yang dilakukan dalam kehidupan para warga kelompok tersebut dirasakan sebagai suatu hal yang biasa (sebagai fenomena biasa dalam kehidupan keseharian mereka). Pada kondisi seperti itu tidak ada yang diacu untuk pamir, sehingga di antara mereka tidak ada perasaan saling berbeda, yang dapat menibulkan perasaan malu. Dalam keadaan demikian, maka kemiskinan terwujud dalam berbagai cara-cara mereka memenuhi kebutuhan-kebutuhan mereka untuk dapat hidup. ${ }^{15}$

Sementara Perserikatan Bangsa-Bangsa (PBB) memandang bahwa kemiskinan memiliki manifestasi yang bervariasi, termasuk keterbatasan pendapatan dan kecukupan sumber daya produksi untuk menjamin mata pencahrian secara terus-menerus, kelaparan dan kurang gizi, kesehatan yang endah, keterbatasan akses pada pendidikan dan pelayanan dasar, peningkatan jumlah penderitaan penyakit dan kematian karena penyakit gelandangan dan rumah kumuh, lingkungan yang tidak sehat, serta diskriminasi sosial dan keterasingan. Kemiskinan juga ditandai dengan keterbatasan pada partisipasi pengambilan keputusan dalam kehidupan sosial budaya masyarakat. ${ }^{16}$

Hingga kini kondisi dan fenomena kemiskinan masih melingkungi sebagian besar masyarakat kita. Kemiskinan bukan lagi sesuatu yang abstrak sifatnya, melainkan sudah berwujud yang bisa diterjemahkan ke dalam berbagai pengertian umum di masyarakat. Masyarakat tidak pernah menyangkal, justru semakin sepakat bahwa kemiskinan itu ada. Di Indonesia seluruh lapisan masyarakat mulai dari kalangan birokrat di tingkat atas sampai masyarakat biasa

\footnotetext{
${ }^{14}$ Bernhard Limbong, Ekonomi Kerakyatan dan nasionalisme..., h. 208

${ }^{15}$ Suparlan parsuadi, 1994 dikutip dari Bernhard Limbong, Ekonomi Kerakyatan dan nasionalisme Ekonomi, (Jakarta: margharetha Pustaka) h. 209

${ }^{16}$ United nations, "World summit for Social Agreement," Programme of Action of the World Summit for Social Development" Copenhagen 1995,2006 dikutip dari Bernhard Limbong, Ekonomi Kerakyatan dan nasionalisme Ekonomi, (Jakarta: margharetha Pustaka) h. 210
} 
di tingkat desa, mengakui keberadaan kemiskinan. Kondisi ini merupakan sebuah persoalan yang mengandung banyak dimensi yang menuntut pemecahannya melalui berbagai pendekatan. Kemiskinan telah melibatkan faktor ekonomi, sosial, budaya dan tentu juga politik. Sehingga tidaklah mengherankan apabila kesulitan akan timbul ketika fenomena kemiskinan diobjektifkan dalam bentuk angka-angka, seperti halnya dalam pengukuran dan penentuan garis batas kemiskinan yang hingga kini masih menjadii perdebatan. ${ }^{17}$

Kemiskinan bukan hanya masalah Indonesia, tetapi merupakan masalah dunia. Di Indonesia, pertumbuhan ekonomi yang tinggi dan berkelanjutan selama era Orde baru (1966-1998) memberi suatu kontribusi yang besar terhadap pengangguran kemiskinan. Keberhasilan pemerintah Orde Baru mengurangi kemiskinan lewat pertumbuhan ekonomi yang itnggi tidak mengatakan bahwa pertumbuhan ekonomi adalah satu-satunya yang diperlukan untuk mengentaskan kemiskinan. Dengan kata lain pertumbuhan ekonomi adalah suatu faktor yang sangat penting bagi penurunan kemiskinan, tetapi bukan satu-satunya penentu. Kebijakan-kebijakan yang 'pro-miskin'sangat diperlukan agar pertumbuhan ekonomi bersifat PPG, yakni yang mempunyai suatu dampak positif yang berarti pengurangan kemiskinan, terutama kebijakankebijakan yang produktif seperti perluasan akses bagi semua orang ke pendidikan dan pelayanan kesehatan, peningkatan kesempatan kerja, dan pembagunan sektor pertanian dan ekonomi perdesaan. ${ }^{18}$

Sejak zaman sebelum kemerdekaan, persoalan kemiskinan telah menjadi fenomena sosial yang melekat dalam kehidupan masyarakat Indonesia. Kendati kemiskinan melekat kepada individu/perorangan, namun pengentasannya bukan semata-mata tanggung jawab individu, melainkan tanggung jawab seluruh komponen negara (bangsa), mulai dari lembaga birokrat/aparat pemerintahan, lembaga swasta, dan sampai kepada seluruh lapisan masyarakat. Kemiskinan merupakan permasalahan sosial yang harus segera diatasi ${ }^{19}$.

Kemiskinan membawa banyak dampak negatif terhadap kehidupan masyarakat suatu negara baik secara materiil maupun secara spritual. Secara materiil kemiskinan dapat terkait dengan hal yang bersifat mendasar seperti kebutuhan makanan, pakaian, rumah, pendidikan, kesehatan, transportasi, dan komunikasi. ${ }^{20}$ Kemiskinan materiil terjadi dikarenakan lemahnya kehidupan ekonomi, ketidakcukupan pendapatan membuat masyarakat kehilangan kemampuan untuk memenuhi kebutuhan dasar.

Banyak faktor yang meyebabkan terjadinya kemiskinan seperti faktor individual (cacat tubuh), faktor sosial (diskriminasi sosial), faktor kultural

\footnotetext{
${ }^{17}$ Bernhard Limbong, Ekonomi Kerakyatan dan nasionalisme..., h. 205

${ }^{18}$ Tulus T.H Tambunan, Perekonomian Indonesia, (Bogor: Ghalia Indonesia, 2012, h. 195

${ }^{19}$ Bernhard Limbong, Ekonomi Kerakyatan dan nasionalisme..., h. 205

${ }^{20}$ Irfan Syauqi Beik dan Laily Dwi Arsyianti, Ekonomi Pembangunan ..., h. 78
} 
(perilaku buruk seperti malas bekerja), dan faktor struktural (ketidakadilan sistem). ${ }^{21}$

Kemiskinan dapat dilihat sebagai keadaan masyarakat dengan tingkat ekonominya masih lemah, dan ditambah dengan kebijakan pemerintah yang umumnya diarahkan untuk memecahkan permasalahan jangka pendek. Sehingga kebijakan tersebut belum berhasil memecahkan kelompok ekonomi rakyat bawah. Di samping itu juga pengaruh keadaan luar negeri, antara lain segi pendanaan pembangunan.

Kemiskinan juga dapat disebabkan karena sifat alamiah/cultural, yaitu masalah yang muncul di masyarakat bertalian dengan pemilikan faktor produksi, produktifitas dan tingkat perkembangan masyarakat itu sendiri. Di samping itu kemiskinan bisa disebabkan oleh masalah struktural, yaitu disebabkan oleh miskinnya strategi dan kebijakan pembangunan nasional yang dilaksanakan. ${ }^{23}$

Ada tiga pendekatan yang mencoba menjelaskan mengenai sebab-sebab kemiskinan, yaitu sistem approach, decision-making model, dan structural approach. Pendekatan pertama lebih adanya keterbatasan pada aspek-aspek geografis, ekologi, teknologi, dan demografi. Kondisi kemiskinan yang disebabkan oleh faktor-faktor tersebut dianggap lebih banyak menekan warga masyarakatyang tinggal di daerah pedesaan atau pedalaman. Pendekatan ini menyarankan dilakukannya intervensi tentu untuk meningkatkan kemampuan daya dukung lingkungan dalam melalui introduksi teknologi baru yang memiliki kemampuan dan kapasitas lebih besar dalam mengekplorasi dan mengekploitasi sumbersumber daya ekonomi, sehingga dapat tercapai surplus produksi serta dapat meningkatkan nilai tambah hasil produksi. Sementara pendekatan kedua menekankan pada kurangnya pengetahuan, ketrampilan, dan keahlian sebagian warga masyarakat dalam merespon sumber-sumber daya ekonomi, baik yang berasal dari dalam maupun dari luar. Dengan kata lain, pendekatan ini melihat bahwa bagian warga masyarakat kurang memiliki kemampuan inovasi atau tidak memiliki empati dan jiwa kewirausahaan (interpreneurship) untuk mengelola secara lebih baik, efisien, dan efektif unit-unit usaha yang mereka miliki atau kuasai. Kurang kemampuan untuk memperbaharui teknologi serta menciptakan dan memperluas pasar komoditi. Karenanya, pendekatan ini mengehendaki ditingkatkannya kemampuan, yakni keahlian dan ketrampilan SDM seperti pembentukan dan pengembangan motivasi, mendorong mobilitas, peningkatan pendidikan pada orang-orang miskin supaya mereka memiliki jiwa-jiwa yang inovatif, kreatif, responsif dan proaktif dalam persaingan. ${ }^{24}$

Sedangkan pendekatan yang ketiga melihat bahwa kemiskinan itu terjadi karena adanya ketimpangan dalam penguasaan dan memiliki faktor-faktor produksi, seperti tanah, teknologi, dan bentuk kapital lainnya. Di sini wajah

\footnotetext{
${ }^{21}$ Irfan Syauqi Beik dan Laily Dwi Arsyianti, Ekonomi Pembangunan ..., h.70

22 Subandi, Ekonomi Pembangunan, (Bandung: Alfabeta, 2014), h. 78

${ }^{23}$ Subandi, Ekonomi..., h. 78

${ }^{24}$ Nur Rianto Al Arif, Teori Makroekonomi Islam, (Bandung: Alfabeta, 2010), h 234
} 
kemiskinan memiliki dimensi struktural, yang merupakan akibat dari adanya ketimpangan dalam pemilikan dan penguasaan aset-aset ekonomi atau kapital lainnya, yang ditunjukkan dengan adanya sebagian anggota masyarakat yang jumlahnya lebih kecil tetapi menguasai dan memiliki faktor-faktor produksi yangg lebih banyak. Sementara sebagian besar warga masyarakat menguasai dan memiliki faktor-faktor produksi yang lebih sedikit. ${ }^{25}$

Menurut Shrap sebagaimana yang dikutip Kuncoro mengidentifikasi ada tiga penyebab kemiskinan dipandang dari sisi ekonomi, yaitu:

a. Secara mikro, kemiskinan muncul karena adanya ketidaksamaan pola kemiskinan sumber daya sehingga menimbulkan distribusi pendapatan yang timpang;

b. Kemiskinan timbul akibat perbedaan kualitas sumber daya manusia;

c. Kemiskinan muncul akibat perbedaan akses dalam modal. Ketika penyebab kemiskinan ini bermuara pada teori lingkaran kemiskinan (vicious circle of poverty). Adanya keterbelakangan, ketidaksempurnaan pasar, dan kurangnya modal menyebabkan rendahnya pendapatan yang mereka terima. Rendahnya pendapatan akan berakibat pada rendahnya tabungan dan investasi. Rendahnya investasi mengakibatkan pada keterbelakangan, dan seterusnya. Logika berfikir ini dikemukakan oleh Ragner Nurkse pada tahun 1953 yang mengatakan bahwa: a poor country is poor because it is poor (negara miskin itu miskin karena miskin). ${ }^{26}$

Kemiskinan mempunyai ukuran yang luas dan tidak mudah untuk mengukurnya, namun demikian, secara umum ada dua macam ukuran kemiskinan yaitu kemiskinan absolut dan kemiskinan relatif. Kalangan pemerhati masalah kemiskinan telah mencoba memilah kemiskinan ke dalam empat bentuk, dimana masing-masing bentuk mempunyai arti tersendiri. Keempat bentuk tersebut yaitu kemiskinan absolut, kemiskinan relatif, kemiskinan struktural dan kemiskinan kultural. ${ }^{27}$

a. Kemiskinan absolut, dapat diukur dengan membandingkan tingkat pendapatan orang dengan tingkat pendapatan yang dibutuhkan untu memperoleh kebutuhan dasarnya. Tingkat pendapatan minimum merupakan pembatas antara keadaan miskin dengan tidak miskin. Konsep ini sering disebut dengan kemiskinan absolut, hal ini dimaksud untuk menentukan tingkat pendapatan minimum yang cukup untuk memenuhi kebutuhan fisik, sepertii makanan, pakaian, dan perumahan untuk menjamin kelangsungan hidup. Kesulitan dalam konsep

\footnotetext{
${ }_{25}$ Nur Rianto Al Arif, Teori Makroekonomi..., h 235

26 Subandi, Ekonomi ..., h. 78

${ }^{27}$ Bernhard Limbong, Ekonomi Kerakyatan dan nasionalisme..., h.211
} 
kemiskinan absolut adalah menentukan komposisi dan tingkat kebutuhan minimum karena kedua hal tersebut tidak hanya dipengaruhi oleh adat kebiasaan saja, tetapi juga tingkat kemajuan suatu negara, dan beberapa faktor ekomomi lainnya.

b. Kemiskinan relatif, adalah orang yang sudah mempunyai tingkat pendapatan yang memenuhi kebutuhan dasar, namun masih jauh rendah dibandingkan keadaan masyarakat sekitarnya, maka orang tersebut masih dianggap miskin. Menurut Miller dalam Arsyad (1999) hal ini terjadi karena kemiskinan lebih banyak ditentukan oleh keadaan sekitar, dan pada lingkungan orang yang bersangkutan. ${ }^{28}$

c. Kemiskinan struktural, adalah kondisi atau situasi miskin karena pengaruh kebijakan pembangunan yang belum mejangkau seluruh masyarakat sehingga menyebabkan ketimpangan pada pendapatan. ${ }^{29}$

d. Kemiskinan kultural karena mengacu kepada persoalan sikap seseorang atau masyarakat yang disebabkan oleh faktor budaya, seperti tidak mau berusaha untuk memperbaiki tingkat kehidupan, malas, pemboros, tidak kreatif, meskipun ada usaha dari pihak luar untuk membantunya. Mempertimbangkan kemiskinan sebagai ketidakmampuan untuk berpartisipasi dalam masyarakat juga mengarah pada konsep kemiskinan relatif. Di negara-negara maju pemenuhan kebutuhan dasar tidak lagi menjadi persoalan rumah tangga, ada penekanan yang lebih mendesak yaitu keterlibatan rumah tangga dalam dimensi sosial yang tidak menjauh dari "mainstream" masyarakat lain. ${ }^{30}$

\section{Indikator Kemiskinan}

Konsep tentang kemiskinan sangat beragam, mulai dari sekedar ketakmampuan memenuhi kebutuhan konsumsi dasar dan memperbaiki keadaan, kurangnya kesempatan berusaha, hingga pengertian yang lebih luas yang memasukan aspek sosial dan moral. ${ }^{31}$

Indikator kemiskinan ada bermacam-macam yaitu: tingkat konsumsi beras perkapita pertahun, tingkat pendapatan, tingkat kecukupan gizi, kebutuhan fisik minimum (KFM) dan tingkat kesehteraan.

a. Tingkat Konsumsi Beras

b. Tingkat Pendapatan

Besar kecilnya jumlah penduduk miskin sangat dipengaruhi oleh garis kemiskinan, karena penduduk miskin adalah penduduk yang memiliki rata-rata pengeluaran per kapita per bulan dibawah garis kemiskinan. Semakin tinggi garis kemiskinan,

\footnotetext{
${ }^{28}$ Subandi, Ekonomi Pembangunan, (Bandung: Alfabeta, 2014), h. 80

${ }^{29}$ Bernhard Limbong, Ekonomi Kerakyatan dan nasionalisme..., h.212

30 Bernhard Limbong, Ekonomi Kerakyatan dan nasionalisme..., h.212

31 Bernhard Limbong, Ekonomi Kerakyatan dan nasionalisme..., h.213
} 
semakin banyak penduduk yang tergolong sebagai penduduk miskin. $^{32}$

c. Tingkat Kesehteraan Sosial

Selain pendapatan dan pengeluaran, ada berbagai komponen tingkat kesejahteraan yang lain yang sering digunakan. Pada publikasi UN (1961) yang berjudul Internasional Definition and Measurement of levels of Livin:An Intern Guide disarankan 9 komponen kesejakteraan yaitu kesehatan, konsumsi makanan dan gizi, pendidikan, kesempatan kerja, perumahan, jaminan sosial, sandang, rekreasi dan kebebasan. ${ }^{33}$

Memang komponen kemiskinan di atas sangat bermanfaat untuk mempermudah membuat indikator orang miskin, tetapi komponen ini sangat kurang memadai karena ; 1) tidak cukup untuk memahami realitas kemiskinan; 2) dapat menjerumuskan ke kesimpulan yang salah bahwa menanggulangi kemiskinan cukup hanya dengan menyediakan bahan makanan yang memadai; 3) tidak bermanfaat bagi pengmabil keputusan ketika harus merumuskan kebijakan lintas sektor, bahkan bisa kontraproduktif. Penentuan indikator kemiskinan dapat dibagi dalam dua pendekatan yakni pendekatan moneter dan pendekatan non moneter. Pendekatan moneter menggunakan faktor-faktor yang berhubungan langsung dengan uang atau faktor -faktor yang dikonversi ke dalam nilai uang. Pendekatan moneter menggunakan nilai pendapatan atau nilai pengeluaran konsumsi tertentu yang dianggap memenuhi kebutuhan dasar yang dijadikan sebagai garis kemiiskinan untuk menentukan status miskin atau tidak miskin. $^{34}$

Pendapatan merupakan konsumsi yang dikurangi dengan perubahan nilai kekayaan bersih. Sedangkan pengeluaran konsumsi merupakan penjualan nilai barang-barang atau jasa yang dibeli dan barang atau jasa yang dihasilkan sendiri. ${ }^{35}$ Pendekatan moneter menggunakan nilai pengeluaran konsumsi karena dianggap lebih baik jika dibandingkkan dengan nilai pendapatan. Alasannya adalah: konsumsi aktual lebih berhubungan dengan kondisikesejahteraan dalam memenuhi kebutuhan dasarnya; konsumsi lebih mudah diukur daripada pendapatan terutama bagi para petani di desa yang kesulitan menentukan pendapatan yang diperoleh mengingat pendapatan tersebut berdasarkan siklus hasil panen; dan konsumsi lebih merefleksikan standar kehidupan rumah tangga dan kemampuan uuntuk memenuhi kebutuhan dasar. ${ }^{36}$

Sedangkan pendekatan non moneter menggunakan faktor-faktor yang tidak berhubungan dengan uang yang diasosisikan dengan kekurangan pada dimensi kesehatan, nutrisi, pendidikan, kepemilikan aset, peran sosial dalam

\footnotetext{
${ }^{32}$ Mudrajad Kuncoro, Indikator Ekonomi, (Yogyakarta: UPP STIM YKPN, 2015) h. 195

33 Subandi, Ekonomi..., h. 81

34 Bernhard Limbong, Ekonomi Kerakyatan dan nasionalisme..., h.214

35 World Bank Institut, Introduction to Poverty analysis, hal. 26-28 dikutip dari Bernhard Limbong, Ekonomi Kerakyatan dan nasionalisme Ekonomi, (Jakarta: margharetha Pustaka) h. 214

36 Bernhard Limbong, Ekonomi Kerakyatan dan nasionalisme..., h.214
} 
masyarakat, ketidakberdayaan dan rendahnya penghargaan dari. ${ }^{37}$ BAPENNAS menggunakan beberapa utama yang mengakomodasi hak-hak dasar masyarakat miskin untuk mempertahankan dan mengembangkan kehidupan yang bermatabat. Pendekatan yang dimaksud mencakup: pendekatan kebuttuhan dasar, pendekatan pendapatan, pendekatan kemampuan dasar, dan pendekatan objektif dan subjektif. ${ }^{38}$

\section{Strategi/ Kebijakan dalam mengurangi Kemiskinan}

\section{a. Pembangunan Pertanian}

Sampai saat ini sektor pertanian masih berperan sangat penting dalam pembangunan ekonomi dan pengurangan kemiskinan di Indonesia. Ada tiga aspek dari pembangunan pertanian yanga aspek terg telah memberikan kontribusi yang cukup besar dalam mengurangi kemiskinan, terutama di daerah pedesaan. Ketiga aspek tersebut antara lain adanya revolusi teknologi pertanian, pembangunan irigasi, serta pembangunan pertanian di luar Jawa dengan pola transmigrasi

b. Pembangunan Sumber Daya Manusia

Pembangunan sumber daya manusia dapat dilakukan dengan perbaikan akses terhadap konsumsi pelayanan sosial (pendidikan, kesehatan dan gizi) merupakan strategi pemerintah yang cukup penting untuk mengurangi kemiskinan dan memperbaiki kesejahteraan penduduk Indonesia. Untuk meningkatkan kualitas layanan tersebut dibutuhkan intervensi modal insani yang pada akhirnya akan meningkatkan produktivitas golongan miskin tersebut.

\section{c. Peranan Lembaga Swadaya Masyarakat (LSM)}

LSM merupakan kelompok NGO yang memiliki peran yang sangat besar dalam perancangan dan implementasi program pengurangan kemiskinan. Karena biasanya mereka sangat pleksibel dan memiliki pengetahuan tentang komunitas yang mereka bina. Dalam beberapa hal bisanya LSM-LSM ini dapat menjangkau golongan miskin secara lebih efektif ketimbang program-program pemerintah. Keterlibatan LSM dalam program-program pemerintah cenderung meningkatkan masyarakat terhadap program-program pemerintah, dengan demikian partisippasi masyarakat akan meningkat. Keterliatan LSM-LSM juga dapat meringankan biaya finansial dan staf dalam mengimplemetasikan program-program padat karya untuk mengurangi kemiskinan.

\footnotetext{
${ }^{37}$ Ade cahyat, "Bagaimana kemiskinan diukur? Beberapa Model Kemiskinan di Indonesia, Governance Brief Number 2 (November 2004), Center for International Forestry Research, h.1 dikutip dari Bernhard Limbong, Ekonomi Kerakyatan dan nasionalisme Ekonomi, (Jakarta: margharetha Pustaka) h. 214

38 Bernhard Limbong, Ekonomi Kerakyatan dan nasionalisme..., h. 214
} 
Bentuk organisasi kemasyarakatan dapat dikelompokkan ke dalam empat kategori:

1) Lembaga swadaya Masyarakat (LSM)

2) Lembaga Pembina Swadaya Masyarakat (LPSM)

3) Organisasi-organisasi sosial lainnya

4) Organisasi-organisasi semi pemerintah ${ }^{39}$

5) Kebijakan dan Program Pemerintah

Komitmen pemerintah dalam melaksanakan pembangunan harus seiring dengan program penanggulangan kemiskinan. Itulah tanggung jawab yang harus dilaksanakan pemerintah. Selama duua dekade pembangunan berbagai program anti kemiskinan telah diciptakan untuk memberantas kemiskinan seperti; program bantuan modal kerja, transmigrasi dan program inpres.

Dalam menangani masalah kemiskinan absolut yang banyak terdapat di wilayah pedesaan kebijakan yang ditetapkan pemerintah harus diarahkan langsung pada pembangunan desa pada umumnya dan sektor pertanian pada khususnya.

\section{Potret Kemiskinan di Indonesia}

Kemiskinan terus menjadi masalah fenomenal sepanjang sejarah Indonesia sebagai nation state, sejarah sebuah negara yang salah memandang dan mengurus kemiskinan. Dalam negara yang salah urus, tidak ada persoalan yang lebih besar, selain persoalan kemiskinan. Kemiskinan telah membbuat juttaan anak-anak tidak bisa mengenyam pendidikan yang berkualitas, kesulitan membiayayi kesehatan, kurangnya tabungan dan tidak adanya investasi, kurangnya akses ke pelayanan publik, kurangnya lapangan pekerjaan, kurangnya jaminan sosial dan perlindungan terhadap keluarga, mengatnya arus urbanisasi ke kota, dan yang lebih parah, kemiskinan menybabkan jutaan rakyat memenuhi kebituhan pangan, sandang dan papan secara terbatas. Kemiskinan menyebabkan masyarakat desa rela mengorbankan apa saja demi keselamatan hidup, safety life, mempertaruhkan tenaga fisik untuk memproduksi keuntungan bagi tengkulak lokal dan menerima upah yang tidak sepadan dengan biaya tenaga yang dikeluarkan. Para buruh tanidesa bekerja sepanjang hari, tetapi mereka menerima upah yang sangat sedikit. ${ }^{41}$

Upaya peningkatan penguasaan IPTEK masyarakat juga bukan perkara yang mudah. Masalah utamanya adalah biaya pendidikan. Tetapi bukan hanya itu, budaya menghargai simbol-simbol formal di masyarakat Indonesia merupakan hal yang sangat menghambat kemajuan pengasaan iptek. Entah sejak kapan, manusia Indonesia merasa lebih terpandang di lingkungan masyarakatnya apabila telah memiliki iazah kesarjanaan daripada memiliki

\footnotetext{
${ }^{39}$ Subandi, Ekonomi..., h. 81-83

40 Michael P. Todaro, Pembangunan Ekonomi di Dunia Ketiga, (Jakarta: Erlangga, 1995), h. 161

41 Bernhard Limbong, Ekonomi Kerakyatan dan nasionalisme..., h. 229
} 
kemampuan nyata untuk menyelesaikan suatu pekerjaan. Akhirnya, dunia pendidikan pun tidak tergerak untuk mencetak manusisa-manusia siap pakai. Sekolah-sekolah kejuruan kurang berkembang. ${ }^{42}$ Persoalan kemiskinan bukan hanya sekedar berapa jumlah dan persentase penduduk miskin. Dimensi lain yang perlu diperhatikan adalah tingkat kedalaman dan keparahan kemiskinan. ${ }^{43}$

\section{Konsep Kemiskinan dalam Islam}

Al-Ghazali mendefinisikan kemiskinan sebagai ketidakmampuan seseorang dalam memenuhi kebutuhan mereka sendiri. Ketidakmampuan untuk memenuhi apa yang tidak dibutuhkan bukanlah kemiskinan. Jika barang yang dibutuhkan tersedia dan terjangkau oleh seseorang, maka dia tidak akan diperlukan sebagai orang miskin. Al-Ghazali membagi kemiskinan menjadi dua bagian; 1) kemiskinan dalam kaitannya dengan kebutuhan material dan 2) kemiskinan dalam kaitannya dengan kebutuhan rohani.

Argumen serupa juga dibuat oleh Ahmad (2004), yang mengatakan kemiskinan bukan hanya merupkan perampasan barang dan jasa, tetapi juga kurangnya kemiskinan dalam roh. Bahkan Rahman (1980) berpendapat bahwa umat Islam dapat meningkatkan kehidupan rohani mereka dengan meningkatkan kehidupan material mareka. Selanjutnya, Chapra (2001) berpendapat bahwa Islam, menjadi agama keseimbangan, telah memberikan penekanan yang sama pada kedua spritual dan urusan duniawi. ${ }^{44}$

Menurut Yusuf Qardhawi (2005) bahawa Islam memandang kemiskinan merupakan satu hal yang mampu membahayakan akhlak, kelogisan berfikir, keluarga dan juga masyarakat. Islampun menganggapnya sebagai musibah dan bencana yang seharusnya memohon perlindungan kepada Allah atas kejahatan yang tersembunyi di dalamnya. Jika kemiskinan itu makin merajalela, maka ini akan menjadi kemiskinan yang mampu membuatnya lupa akan Allah dan juga rasa sosialnya kepada sesama. Ini bagaikan seorang kaya yang apabila terlalu menjadi seperti raja, maka kekayaannya menjadikannya seperti seorang yang zalim, baik kepada Allah maupun kepada manusia lainnya. Ada beberapa bentuk kezaliman kepada Allah, zalim kepada manusia dan zalim kepada dirinya sendiri. ${ }^{45}$

Banyak sahabat Rasulullah SAW yang meriwayatkan, bahwasannya Rasulullah SAW sendiri pernah memohon perlindungan Allah SWT dari kemiskinan. Abalila memang kemiskinan tidak berbahaya, maka tentunya Rasulullah tidak perlu meminta permohonan perlindungan kepada Allah dari kemiskinan. Sebagaimana yang diterangkan dalam hadist berikut:

"Ya Allah, sesungguhnya aku berlindung pada-Mu dari fitnah api neraka, dan aku berlindung kepada-Mu dari Fitnah kekayaan dan juga

\footnotetext{
${ }^{42}$ Bernhard Limbong, Ekonomi Kerakyatan dan nasionalisme..., h. 230

${ }^{43}$ Bernhard Limbong, Ekonomi Kerakyatan dan nasionalisme..., h. 235

${ }^{44}$ Nurul Huda, Ekonomi Pembangunan Islam, (Jakarta: Prenada Media, 2015), h. 23

${ }^{45}$ Nurul Huda, Ekonomi..., h. 23
} 
berlindung pada-Mu atas fitnah kemiskinan." (HR. Abu Daud, Nasa'I dan Ibnu Majjah)

Tampak dari Hadist tersebut sesungguhnya Rasulullah SAW berlindung Kepada Allah SWT dari semua hal yang melemahkan baik secara materi maupun secara maknawi, baik kelemahan baik secara materi maupun maknawi, baik kelemahan itu karena tidak mempunyai uang (kemiskinan), atau tidak mempunyai harga diri dan juga karena hawa nafsu (kehinaan). ${ }^{46}$ yaitu:

Dalam sudut pandang Islam kemiskinan terbagi menjadi tiga tingkatan

a. Kemiskinan iman, yaitu orang yang jiwanya tidak ada kontak atau hubungan dengan Allah, atau jika ada hubungan pun terlalu tipis, yaitu hanya ingat kepada Allah saat susah saja. Jadi bila orang jiwanya sudah tidak ada kontak dengan Allah, maka artinya dia sudah tidak memberikan kasih sayang atau cinta kepada Allah. Kalau seorang hamba sudah tidak memberikan kasih sayang kepada Allah yang telah menciptakannya, maka bagaimana Allah mau memberi kasih sayang kepada mereka, maka akhirnya Allah membiarkan mereka terombang-ambing, hidup sendiri-sendiri, tiada panduan dan pimpinan, dsb. Inilah yang kita lihat di seluruh dunia ini, peperangan, kemiskinan, perkelahian, bentrokan, krisis, dan berbagai macam kemungkaran yang menyusahkan mereka sendiri. Krisis mulitidimensi yang melanda bangsa ini pun ditenggarai oleh meningkatnya krisis iman seseorang, memang banyak orang yang mendapatkan gelar "haji" tetapi gelar yang disandangnya hanyalah sebagai gengsi semata dan tidak melekat kepada individu tersebut dalam perilaku kehidupan sehari-hari.

b. Miskin ilmu. Ilmu menjadi peknyebab kedua mengapa manusia mengalami kesusahan, miskin atau tidak tahu bagaimana menyelesaikan masalah hidup. Saat ini etos kerja umat Islam sangat rendah, mereka enggan untuk mengkaji ilmu-ilmu Allah, padahal wahyu yang diturunkan Allah pertama kali adalah perintah untuk membaca. Namun saat ini membaca belumlah menjadi budaya yang tercipta dalam tubuh setiap musli, hal ini yang menjadi salah satu penyebab tertinggal dan keterbelakangan kaum muslim dibandingkan dengan kaum non muslim, terutama di negara-negara berkembang seperti Indonesia.

c. Miskin harta, yaitu kemiskinan yang mencakup tidak dapat memenuhi makan dan minum, tidak dapat membangun rumah, tidak dapat berkemajuan dsb. Adalah buah dari manusia yang tidak ada kontak dengan Allah dan buah dari manusia yang tidak memeliki ilmu. Dalam menentukan suatu ukuran yang pasti tentang batas seseorang dapat disebut dalam kondisi miskin tidak mudah pula bagi ulama Islam. Para ulama mazhab Malikiyah, syafii'iyah dan Hanabilah mendefinisikan miskin adalah sebagai seseorang yang masih memiliki kemampuan untuk bekerja, berusaha dalam rangka memperoleh harta dan menghidupi keluarganya secara halal tetapi hasil yang didapat masih

\footnotetext{
${ }^{46}$ Nurul Huda, Ekonomi..., h. 24
} 
belum mencukupi bagi pemenuhan kebutuhan dirinya dan keluarganya. Sementara golongan Hanafiyah memandang miskin sebagai orang yang tidak memiliki sesuatu (baik harta maupun tenaga), sehingga tidak ada kemampuan dari orang tersebut untuk memnuhi kebutuhan hidupnya dan keluarga. Ada dua faktor penyebab seseorang atau kelompok orang masuk dalam kemiskinan, yaitu faktor internal dan faktor internal. ${ }^{47}$

Menurut Manawy (2003) antara kekafiran dan kekufuran mempunyai keterkaitan yang sangat kuat, karena kekufuran merupakan merupakan satu langkah menuju kekafiran. Seorang yang fakir miskin, pada umumnya akan menyimpan kedengkian kepada orang yang mampu dan kaya. Adapun iri dengki mampu menlenyapkan kebaikan. Merekapun mulain menumbuhkan kehinaan di dalam hati mereka, disaat mereka mulai melancarkan segala daya upanya demi mencapai tujuan kedengkian mereka terebut. Kesemuanya ini mampu meniadai agamanya dan juga menimbulkan adanya ketidakridhaan atas takdir yang telah ditetapkan yang akhirnya tanpa sadar akan membuatnya mencela rezeki yang telah datang padanya. Walaupun ini semua belum termasuk kedalam kekafiran, namun sudah merupakan langkah untuk mencapai kekafiran tu sendiri. ${ }^{48}$

Qardhawi (1996) menyatakan beberapa pendirian terhadap masalah kemiskinan. Pertama, pendirian yang menyucikan kemiskinan. Bagi golongan ini kemiskinan bukan masalah yang harus dipecahkan, tetapi harus dibiarkan, karena dengan demikian manusia bisa berkonsentrasi berhubungan dengan Tuhannya tidak diganggu dengan urusan duniawi. Kedua, pendirian para fatalis yang menganggap bahwa kemiskinan itu merupakan takdir Allah dan manusai harus sabar dengan ujian itu, ketiga, pendirian kertiga sama dengan fatalis, namun mereka maju selangkah yaitu secara perorangan mereka harus membantu orang-orang miskin. Madzhab ini dikenal sebagai "kebijakan pribadi". Keempat, kaum kapitalis memandang kemiskinan menimbulkan problem yang harus diselesaikan dengan orang miskin sendiri,sedangkan orang kaya bebas dalam menggunakan hartanya. Kelima, kaum Marxis yang menyatakan bahwa kemiskinan itu bisa diatasi kalau kaum borjuis dan kekayaannya tidak dimusnahkan, tetapi ditata kelas-kelas baru. ${ }^{49}$

\section{Pengentasan Kemiskinan}

Dikarenakan kemiskinan menimbulkan banyak dampak negatif maka diperlukan berbagai cara untuk memperbaiki keadaan agar yang tadinya kurang baik menjadi lebih baik, atau yang tadinya miskin menjadi sejahtera. Dalam pandangan Islam ketika berbicara mengenai kemiskinan, maka yang ditekankan adalah upaya perhatian perhatian, pembelaan, dan perlindungan terhadap kelompok miskin yang dilakukan oleh mereka yang dikategorikan kelompok

\footnotetext{
${ }^{47}$ Nur Rianto Al Arif, Teori Makroekonomi ..., h. 231-232

${ }^{48}$ Nurul Huda, Ekonomi..., h. 23

${ }^{49}$ Nurul Huda, Ekonomi..., h. 25
} 
kaya. Kelompok kaya diharapkan dapat mengoptimalkan potensi yang dimiliki sehingga tingkat kemiskinan masyarakat dapat diminimalisir.

Menurut al-Maududi (1980), untuk mengatasi kemiskinan, maka yang akan digunakan dan diterapkan yaitu sistem ekonomi Islam dengan karakteristik, sebagai berikut: 1) berusaha dan bekerja; 2) larangan menmpuk harta 3) zakat 4) hukum waris 5) gianimah 6) hemat. ${ }^{50}$

Dari model yang dikemukakan Abul A'la al-Maududi, tentu yang masih relevan untuk diterapkan tentunya lima poin dari enam poin di attas, karena saat ini konsep ganimah sudah tidak ada lagi.

Muhammad Yunus (2007) mengusahkan bahwa dirinya terlibat dalam masalah kemiskinan bukan sebagai pengambil kebijakan atau peneliti. Ia terlibat karena kemiskinan ada dimana-mana di sekelilingnya, dan ia tidak bisa berpaling darinya. Pada 1974, ia merasa sulit mengajarkan teori-teori ekonomi yang elegan di ruang-ruang kelas universitas dengan latar bencana kelaparan yang mengenaskan di Bangladesh. Untuk mengatasi kemiskinan di sekitarnya, Yunus melakukan :

1) Membuat daftar korban "bisnis" rentenir di desa yang bersebelahan dengan kampus tempat ia mengajar. Dari 42 korban yang pinjaman totalnya AS $\$ 27$, kemudia ia mengeluarkan AS $\$ 27$ dari koceknya sendiri untuk membebaskan para korban ini dari cengkeraman rentenir.

2) Menjadi penjamin kredit bank bagi kaum miskin. Ia terkesima oleh hasilnya. Orang-orang miskin yang ia jamin dapat membayar kembali pinjamannya, tepat waktu.

3) Pada 1983, ia mendirikan bank tersendiri bagi kaum miskin yang diberi nama Grameen Bank atau Bank Pedesaan, dan kepemilikan penuh berada di tangan kaum miskin. Hingga 2007, Grameen bank telah memberi kredit ke hampir 7 juta orang miskin di 73.000 desa Bangladesh, 97 persen di antaranya perempaun. Grameen Bank memberi kredit bebas agunan untuk mata pencarian, perumahan, sekolah, dan usaha mikro untuk keluargakelarga miskin dan menawarkan setumpuk program tabungan yang aktraktif, dana pensiun, dan asuransu untuk para anggotanya. Secara akumultif Grameen Bank telah memberi kredit sebesar AS\$6 miliar, dengan tingkat pengembalian 99 persen.

4) Grameen kemudian mendirikan perusahaan yang sahamnya mayoritas dimiliki oleh kaum miskin. Salah satunya yaitu pabrik youghyrt yang diperkaya untuk memberikan asupan gizi bagi anak-anak kurang gizi, sebaggai sebuah perusahaan patungan dengan Danone.

\section{Model CIBEST}

Model CIBEST adalah model penghitungan kemiskinan dan kesejahteraan yang didasarkan kepada kemampuan pemenuhan kebutuhan material dan spiritual. Yang menjadi isu pokok dalam model ini adalah,

\footnotetext{
${ }^{50}$ Nurul Huda, Ekonomi..., h. 25
} 
bagaimana menetapkan standar kebutuhan material dan spiritual ini, sehingga memudahkan dalam menganalisis apakah suatu keluarga atau rumah tangga masuk ke dalam kelompok keluarga sejahtera, keluarga miskin material, keluarga miskin spiritual, maupun keluarga miskin absolut. ${ }^{51}$

Model CIBEST merupakan sebuah metode yang digunakan untuk pengentasan kemiskinan baik material, spritual, maupun absolut dengan cara pemetaan kondisi keluarga atau rumah tangga, sehingga dapat diusulkan program pengentasan kemiskinan yang tepat. Pemetaan kebutuhan material didasarkan pada kebutuhan makanan, pakaian, rumah, pendidikan, kesehatan, transportasi, dan komunikasi. Penghitungan kebutuhan materail model CIBEST dapat dijelaskan dengan formula $\quad \mathrm{MV}=\sum_{i=1}^{n} P_{i . M i} \mathrm{MV}$ merupakan standar minimal kebutuhan materiil yang harus dipenuhi rumah tangga, Pi merupakan harga barang dan jasa, Mi merupakan jumlah minimal barang dan jasa yang diperlukan. Suatu rumahtangga dikatakan mampu secara materiil jika pendapatan mereka berada diatas nilai MV, dimana nilai MV dapat didasarkan pada nilai standar kemiskinan yang dikeluarkan pemerintah (BPS) $)^{52}$

Model CIBEST menggunakan rumah tangga sebagai unit analisis karena Islam memandang bahwa unit terkecil dalam masyarakat adalah keluarga atau rumah tangga. Model CIBEST terdiri dari 4 kuadran yang dibagi berdasarkan pada kemampuan rumah tangga untuk memenuhi kebutuhan materiil dan spiritual yaitu kuadran sejahtera (kuadran ke 1), kuadran kemiskinan material (kuadran 2). Kuadran kemiskinan spritual (kuadran 3), kuadran kemiskinan absolut (kuadran 4).

Kuadran CIBEST membagi kemampuan rumah tangga untuk memenuhi kebutuhan material dan spiritual ke dalam dua tanda, yaitu tanda positif $(+)$ dan negatif $(-)$. Tanda $(+)$ artinya rumah tangga tersebut mampu memnuhi kebutuhannya dengan baik. Tanda (-) artinya rumahtangga tersebut tidak mampu memenuhi kebutuhannya dengan baik. Dengan pola seperti ini, maka didapat empat kemungkinan, yaitu tanda $(+)$ pada pemenuhan kedua kebutuhan material dan spiritual, tanda $(+)$ pada salah satu kebutuhan saja, apakah tanda $(+)$ pada kebutuhan material ataupun tanda $(+)$ pada kebutuhan spiritual saja, serta (-) pada kedua kebutuhan material dan spiritual ${ }^{53}$ Empat kemungkinan inilah yang kemudian melahirkan empat kuandran, di mana sumbu horizontal melambangkan garis kemiskinan materiil dan sumbu vertikal melambangkan garis kemiskinan spiritual.

Pada kuadran pertama, rumahtangga mampu memenuhi kebutuhan kebutuhan materiil dan spiritual sehingga tanda keduanya adalah (+). Inilah kuandran kesejahteraan. Kesejahteraan itu adalah manakala rumah tangga atau

51 Irfan Syauqi Beik, Konsep Dasar Model CIBEST, (Iqtishodia; Jurnal Ekonomi Islam Republika, Kamis 28 Mei 2015), diakses tanggal 11 September 2017

${ }^{52}$ Irfan Syauqi Beik dan Laily Dwi Arsyianti, Ekonomi Pembangunan ..., h. 7

${ }^{53}$ Irfan Syauqi Beik dan Laily Dwi Arsyianti, Ekonomi Pembangunan..., h. 76 
keluarga dianggap mampu baik secara materiil maupun secara spritual. Secara ekonomi produktif, secara ibadah juga produktif. Pada Kuadran kedua rumah tangga mampu memenuhi kebutuhan spritual $(+)$ akan tetapi tidak mampu memenuhi kebutuhan materiilnya (-) dengan baik. Kondisi ini, mencerminkan kondisi rumah tangga yang berada pada kategori kemiskinan materiil. Sebaliknya, pada kuadran III, kondisi yang terjadi adalah rumah tangga tergolong mampu secara materiil $(+)$ namun tergolong tidak mampu secara spiritual (-), sehingga mereka berada pada kategori kemiskinan spiritual, yang terburuk adalah posisi rumah tangga pada kuadran IV. Pada kuadran ini, rumah tangga atau keluarga tidak mampu memnuhi kebutuhan materiil dan spiritualnya secara sekaligus, sehingga tanda keduanya adalah (-). Inilah kelompok yang berada pada kategori kemiskinan absolut. Miskin secara materi dan miskin secara rohani. ${ }^{54}$.

Manfaat dari kuadran CIBEST ini adalah terkait dengan pemetaan kondisi keluarga atau rumah tangga, sehingga dapat diusulkan program pembangunan yang tepat, terutama dalam mentranformasikan semua kudran yang ada agar bisa berada pada kuadran I (kuadran sejahtera). Pada rumah tangga yang berada di kuadran II, maka program kemiskinan melalui (1) peningkatan skiil dan kemampuan rumah tangga, (2) pemberian akses permodalan dan pendampingan usaha, dapat secara efektif dilakukan. Sementara bagi bagi rumah tangga di kuadran III, program yang perlu dikembangkan adalah bagaimana mengajak mereka untuk melaksanakan ajaran agama dengan lebih baik. Misalya jika mereka miskin rohani karena tidak mau berzakat, maka melakukan edukasi tentang zakat dan mendorong mereka berzakat adalah program yang paling tepat. ${ }^{55}$. Sedangkan bagi rumah tangga kuadran IV, maka yang harus dilakukan adalah (1) memperbaiki sisi ruhiyah dan mentalnya terlebih dahulu, baru kemudian (2) memperbaiki kondisi kehidupan ekonominya. Membangun karakter yang berakhlakul karimah adalah modal yang sangat berharga dalam mentranformasikan kaum dhuafa agar menjadi lebih sejahtera ${ }^{56}$.

Dalam upaya memperbaiki kemiskinan, memperbaiki keadaan yang tadinya kurang baik menjadi lebih baik, atau yang tadinya miskin menjadi sejahtera, maka dapat digunakan model CIBEST yang berguna untuk menemukan berbagai program pengentasan kemiskinan yang dirumuskan dengan cara pemetaan keluarga miskin berdasarkan kemiskinan material, spritual, dan absolut.

Model CIBEST menggunakan rumah tangga sebagai unit analisis karena Islam memandang bahwa unit terkecil dalam masyarakat adalah keluarga atau rumah tangga. Model CIBEST terdiri dari 4 kuadran yang dibagi berdasarkan pada kemampuan rumah tangga untuk memenuhi kebutuhan materiil dan

\footnotetext{
${ }^{54}$ Irfan Syauqi Beik dan Laily Dwi Arsyianti, Ekonomi Pembangunan..., h. 77

${ }^{55}$ Irfan Syauqi Beik dan Laily Dwi Arsyianti, Ekonomi Pembangunan..., h. 78

${ }^{56}$ Irfan Syauqi Beik dan Laily Dwi Arsyianti, Ekonomi Pembangunan..., h. 78
} 
spiritual yaitu kuadran sejahtera (kuadran ke 1), kuadran kemiskinan material (kuadran 2). Kuadran kemiskinan spritual (kuadran 3), kuadran kemiskinan absolut (kuadran 4).

Kuadran CIBEST membagi kemampuan rumah tangga untuk memenuhi kebutuhan material dan spiritual ke dalam dua tanda, yaitu tanda positif $(+)$ dan negatif $(-)$. Tanda $(+)$ artinya rumah tangga tersebut mampu memnuhi kebutuhannya dengan baik. Tanda (-) artinya rumahtangga tersebut tidak mampu memenuhi kebutuhannya dengan baik.Dengan pola seperti ini, maka didapat empat kemungkinan, yaitu tanda $(+)$ pada pemenuhan kedua kebutuhan material dan spiritual, tanda $(+)$ pada salah satu kebutuhan saja, apakah tanda $(+)$ pada kebutuhan material ataupun tanda $(+)$ pada kebutuhan spiritual saja, serta $(-)$ pada kedua kebutuhan material dan spiritual ${ }^{57}$ Empat kemungkinan inilah yang kemudian melahirkan empat kuandran, di mana sumbu horizontal melambangkan garis kemiskinan materiil dan sumbu vertikal melambangkan garis kemiskinan spiritual.

Pada kuadran pertama, rumahtangga mampu memenuhi kebutuhan kebutuhan materiil dan spiritual sehingga tanda keduanya adalah $(+)$. Inilah kuandran kesejahteraan. Kesejahteraan itu adalah manakala rumah tangga atau keluarga dianggap mampu baik secara materiil maupun secara spritual. Secara ekonomi produktif, secara ibadah juga produktif. Pada Kuadran kedua rumah tangga mampu memenuhi kebutuhan spritual $(+)$ akan tetapi tidak mampu memenuhi kebutuhan materiilnya (-) dengan baik. Kondisi ini, mencerminkan kondisi rumah tangga yang berada pada kategori kemiskinan materiil. Sebaliknya, pada kuadran III, kondisi yang terjadi adalah rumah tangga tergolong mampu secara materiil $(+)$ namun tergolong tidak mampu secara spiritual (-), sehingga mereka berada pada kategori kemiskinan spiritual, yang terburuk adalah posisi rumah tangga pada kuadran IV. Pada kuadran ini, rumah tangga atau keluarga tidak mampu memnuhi kebutuhan materiil dan spiritualnya secara sekaligus, sehingga tanda keduanya adalah (-). Inilah kelompok yang berada pada kategori kemiskinan absolut. Miskin secara materi dan miskin secara rohani. ${ }^{58}$.

Manfaat dari kuadran CIBEST ini adalah terkait dengan pemetaan kondisi keluarga atau rumah tangga, sehingga dapat diusulkan program pembangunan yang tepat, terutama dalam mentranformasikan semua kudran yang ada agar bisa berada pada kuadran I (kuadran sejahtera). Pada rumah tangga yang berada di kuadran II, maka program kemiskinan melalui (1) peningkatan skiil dan kemampuan rumah tangga, (2) pemberian akses permodalan dan pendampingan usaha, dapat secara efektif dilakukan. Sementara bagi bagi rumah tangga di kuadran III, program yang perlu dikembangkan adalah bagaimana mengajak mereka untuk melaksanakan ajaran

\footnotetext{
${ }^{57}$ Irfan Syauqi Beik dan Laily Dwi Arsyianti, Ekonomi Pembangunan..., h. 76

${ }^{58}$ Irfan Syauqi Beik dan Laily Dwi Arsyianti, Ekonomi Pembangunan..., h. 77
} 
agama dengan lebih baik. Misalya jika mereka miskin rohani karena tidak mau berzakat, maka melakukan edukasi tentang zakat dan mendorong mereka berzakat adalah program yang paling tepat. ${ }^{59}$. Sedangkan bagi rumah tangga kuadran IV, maka yang harus dilakukan adalah (1) memperbaiki sisi ruhiyah dan mentalnya terlebih dahulu, baru kemudian (2) memperbaiki kondisi kehidupan ekonominya. Membangun karakter yang berakhlakul karimah adalah modal yang sangat berharga dalam mentranformasikan kaum dhuafa agar menjadi lebih sejahtera ${ }^{60}$.

\section{Hasil dan Pembahasan}

Berdasarkan temuan temuan yang diperoleh dilapangan dari hasil pengamatan terhadap 42 rumahtangga muslim di Kelurahan Malabro Kecamatan Teluk Segara Kota Bengkulu, dengan menggunakan model CIBEST dapat dikelompokan kondisi aktual kemiskinan di Kelurahan Malabro. Hasil pengelompokan ini akan dijadikan sebagai dasar dalam pembentukan kuadran CIBEST yang nantinya kuadran ini akan dijadikan sebagai pedoman dalam menyusun dan menguraikan berbagai program pengentasan kemiskinan di Kelurahan Malabro.

Konsep kemiskinan berdasarkan model CIBEST ditinjau dari dua aspek yaitu kemiskinan materiil dan kemiskinan spritual. Kebutuhan materiil bersifat mendasar seperti kebutuhan makanan, pakaian, rumah, pendidikan, dan kesehatan. Pemenuhan kebutuhan materiil (materiil value $=$ MV) diukur dengan membandingkan antara nisab zakat penghasilan dengan pendapatan rumahtangga. Jika nilai nisab zakat penghasilan lebih besar dari pendapatan rumahtangga, maka rumahtangga tersebut dikelompokan kedalam rumahtangga yang tidak mampu memenuhi kebutuhan materiilnya (miskin materiil). Sebaliknya jika nilai nisab zakat penghasilan lebih kecil dari pendapatan rumahtangga, maka rumahtangga tersebut dikatakan mampu memenuhi kebutuhan materiilnya (kaya materiil). Nilai nisab zakat penghasilan dihitung $2,5 \%$ dari 85 gram emas dengan masa satu tahun. ${ }^{61}$

Berdasarkan analisis data primer yang diperoleh dari sampel teoritis (42 rumahtangga muslim di Kelurahan Malabro) dengan membandingkan pendapatan setiap rumahtangga muslim dengan nilai nisab zakat penghasilan, dapat dikelompokan kondisi aktual kemiskinan materiil di Kelurahan Malabro. 42 rumahtangga muslim yang diamati, 2 diantaranya dikelompokan kedalam rumahtangga yang kaya materiil dikarenakan pendapatan yang mereka terima setiap bulannya berada diatas nilai nisab zakat penghasilannya. sementara itu, 40 rumahtangga muslim lainnya termasuk rumahtangga yang tidak mampu memenuhi kebutuhan dasar karena pendapatan mereka berada dibawah nilai

\footnotetext{
${ }^{59}$ Irfan Syauqi Beik dan Laily Dwi Arsyianti, Ekonomi Pembangunan..., h. 78

${ }^{60}$ Irfan Syauqi Beik dan Laily Dwi Arsyianti, Ekonomi Pembangunan..., h. 78

${ }^{61}$ Gus Arifin, 2016, Keutamaan Zakat, Infak, Sedekah, Jakarta: Gramedia, h. 75
} 
nisab zakat penghasilan, sehingga ke 40 rumahtangga muslim ini dikelompokan ke dalam kelompok rumahtangga miskin materil.

Tingginya angka kemiskinan materiil disebabkan karena sebagian besar profesi kepala rumahtangga adalah nelayan (lihat tabel 4.1). Sebagai nelayan tingkat produktivitas kerja mereka sangat tergantung kepada kondisi alam yang tidak menentu.. Mereka hanya akan pergi melaut jika cuaca bagus, tidak hujan, dan tidak badai. Dengan aktivitas pekerjaan yang tergantung dengan kondisi alam sangat sulit bagi nelayan untuk memperoleh pendapatan secara rutin, sulit memperoleh pendapatan yang mampu memenuhi kebutuhan materiil keluarga. Selain karena ketergantungan kepada kondisi alam, penyebab lain rendahnya nilai pendapatan yang diperoleh disebabkan keterbatasan peralatan untuk menangkap hasil laut. Kebanyakan peralatan yang digunakan masih tradisional dan dalam jumlah yang terbatas ${ }^{62}$. Sementara itu, para istri nelayan kebanyakan juga hanya berprofesi sebagai ibu rumahtangga yang tidak bisa membantu suami secara materiil.

Kebutuhan spritual berkaitan dengan pemenuhan kebutuhan keimanan terhadap Allah Swt. Pemenuhan kebutuhan spritual dikaitkan dengan variabel shalat, puasa, zakat, infak, sedekah, lingkungan keluarga, dan kebijakan pemerintah yang berkaitan dengan ibadah. Pemenuhan kebutuhan spritual dihitung dari standar pemenuhan kelima variabel diatas berdasarkan nilai skala likert antara 1 sd 5, dengan nilai rata rata rumahtangga miskin secara spritual adalah 3 (SV = 3). Jika nilai kebutuhan spritual rumahtangga $>3$ maka dikatakan rumahtangga tersebut kaya spritual (SS >SV), sebaliknya jika nilai kebutuhan spritual rumahtangga $<3$ maka dikatakan rumahtangga tersebut miskin spritual $(\mathrm{SS}<\mathrm{SV})$.

Berdasarkan analisis data primer yang diperoleh dari sampel teoritis (42 rumahtangga muslim di Kelurahan Malabro) menunjukan keseluruhan rumahtangga merupakan rumahtangga yang mampu memenuhi kebutuhan spritual karena nilai SS $>$ SV atau nilai SS $>3$ ). Sehingga dengan demikian seluruh rumahtangga muslim yang diamati dikelompokan kedalam kelompok rumahtangga kaya spritual. Tidak terdapatnya rumahtangga miskin spritual di Kelurahan Malabro lebih disebabkan karena latar belakang budaya narasumber dan masyarakat Kelurahan Malabro lainnya yang hampir 100\% berasal dari daerah minangkabau (Padang). Masyarakat minang adalah masyarakat arif dan kaya dengan kebudayaan dan filosofi dan lekat dengan nilai syariat islam, sehingga dalam menjalani kehidupan semuanya sesuai dengan kitab suci AlQur'an, ${ }^{63}$ sebagaimana falsafah hidup masyarakat minang "adat basandi syarak, syarak basandi Kitabullah”. Artinya segala adat istiadat yang berlaku , segala aspek kehidupan yang dijalani harus berpedoman kepada Al-Qur'an. Falsafah

62 Hasil Wawancara Dengan Narasumber, Ketua RT 9 Kelurahan Malabro Kecamatan Teluk Segara Kota Bengkulu, Mei 2017, jam 11.00 WIB

63 Wacana, Pandangan Hidup Orang Minang, googleweblight.com/ lite, diakses jumat 13 Oktober 2017, jam 04.55 WIB 
hidup ini yang selalu diingat dan dijalani masyarakat minang dalam kondisi apapun termasuk dalam kondisi miskin materiil.

Indeks CIBEST dalam setiap kuadran menjelaskan 4,74\% rumahtangga muslim di Kelurahan Malabro hidup dalam kondisi sejahtera (kuadran I), 95,26\% dalam kondisi miskin materiil, (kuadran II), dan tidak ada rumahtangga yang diamati berada dalam kuadran III (miskin spritual) dan kuadran IV (miskin absolut).

Berdasarkan hasil indeks CIBEST atas rumahtangga muslim yang diamati di Keluarahan Malabro, maka pemerintah Kota Bengkulu harus menjadikan rumahtangga yang berada pada kuadran II sebagai target utama program pengentasan kemiskinan dan pemberdayaan masyarakat. Desain program pengentasan kemiskinan di kuadran II harus ditekankan pada penguatan dari sisi materiil agar dapat meningkatkan kesejahteraan materiil rumahtangga, dan meningkatkan status rumahtangga dari mustahik menjadi muzzaki.

Dengan berpedoman pada hasil indeks CIBEST serta melihat potensi dan kelemahan yang dimiliki masyarakat dan wilayah Kelurahan Malabro, dapat diusulkan beberapa program pengentasan kemiskinan dan pemberdayaan masyarakat sebagai berikut :

\section{Penyaluran dana zakat konsumtif}

Zakat menjadi instrumen ibadah yang memiliki nilai sosial ekonomi yang sangat kuat. Dalam Islam zakat diwajibkan bagi kaum muslimin yang memiliki kemampuan dalam hal kekayaan untuk dibagikan sebagian kepada kaum fakir miskin dengan tujuan untuk mengurangi atau mengeliminasi tingkat kemiskinan sebagaimana yang dijelaskan dalam UU No 23 Tahun 2011. Hal ini diperkuat dengan pendapat Al-Maudi bahwa salah satu instrumen yang dapat digunakan untuk pengentasan kemiskinan adalah zakat. ${ }^{64}$

Dalam jangka pendek pengentasan kemiskinan dapat dilakukan dalam bentuk penyaluran zakat konsumtif yang diberikan kepada 8 asnaf guna memenuhi kebutuhan dasar materiil, dimana penyaluran zakat konsumtif sendiri harus memenuhi skala prioritas dengan memperhatikan prinsip pemerataan, dan keadilan. Agar penyaluran zakat konsumtif efektif, diperlukan peranan aktif dari lembaga amil zakat seperti Badan Amil Zakat Nasional (BAZNAS) Kota Bengkulu dan badan amil zakat lainnya. Penyaluran zakat konsumtif sebaiknya dilakuka secara kontinu agar kemiskinan materiil yang terjadi di Kelurahan Malabro dapat dientaskan. Selain dilakukan secara kontinu penyaluran zakat konsumtif sebaiknya digandengkan dengan pola penyaluran dalam zakat produktif agar kemiskinan di kelurahan malabro dapat dientaskan dalam jangka panjang.

\section{Penyaluran dana zakat produktif}

64 Nurul Huda. 2015. Ekonomi Pembangunan Islam. Jakarta : Prenadamedia Group. h.25 
Penyaluran dana zakat konsumstif hanya akan bermanfaat dalam jangka pendek. Maka setelah kebutuhan dasar mustahik terpenuhi diperlukan program penyaluran zakat yang dapat didayagunakan untuk usaha produktif sehingga dalam jangka panjang dapat memeperbaiki kondisi kemiskinan materiil yang terjadi di Kelurahan Malabro. Sesuai dengan UU No 23 Tahun 2011, dana zakat produktif yang disalurkan kepada penerimanya harus diinvestasikan pada usaha halal sesuai dengan peraturan dan syariat yang berlaku. Agar penyaluran dana zakat produktif efektif dalam pengembangan usaha mustahik layak untuk di dampingi dan diawasi oleh pihak yang berkompeten yaitu lembaga yang mengelola dana investasi seperti BAZNAS Kota Bengkulu dan badan amil zakat lainnya.

Penyaluran dana zakat produktif dapat diberikan modal usaha, alat alat usaha, pelatihan keterampilan, serta bimbingan usaha. Dengan adanya penyaluran zakat produktif terhadap mustahik secara efektif diharapkan para mustahik dapat hidup mandiri sehingga tidak butuh menerima zakat lagi ketika ekonomi mereka sudah mapan sehingga dengan demikian kemiskinan materiil yang terjadi di Kelurahan Malabro dapat dikurangi secara bertahap dan berkesinambungan dan diharapkan status mustahik dapat berubah menjadi muzzaki.

\section{Bantuan modal kerja untuk rumahtangga miskin}

Dalam mengatasi kemiskinan materiil upaya lain yang dapat dilakukan selain penyaluran dana zakat konsumtif dan produktif adalah dalam bentuk program pemberdayaan masyarakat untuk mendapatkan bantuan modal kerja. Pemerintah Kota Bengkulu dapat menjadi program ini sebagai salah satu program pengentasan kemiskinan di Kelurahan Malabro dengan cara menyalurkan modal usaha melalui kelompok masyarakat yang diberikan kepada wirausahawan pemula yang memiliki usaha mikro dan kecil.

Pemerintah juga bisa melaksanakan program penanggulangan kemiskinan berbasis pemberdayaan usaha mikro dan kecil dengan program kredit usaha rakyat (KUR) yang khusus diperuntukan bagi usaha kecil dan mikro (KUR mikro) dengan flafon nilai pembiayaan sampai batas tertentu. pelaksanaan program KUR mikro dan kecil ini diharapkan dapat mengakselerasi pengembangan kegiatan perekonomian sektor riil di Kelurahan Malabro (terutama usaha produktif) sehingga dapat meningkatkan pendapatan masyarakat, memperluas kesempatan kerja. Dan mampu menangulangi kemiskinan materiil yang terjadi di Kelurahan Malabro. Selain diperlukan peran aktif dari pemerintah Kota Bengkulu, pelaksanaan KUR dan kecil juga memerlukan keterlibatan aktif dari lembag swasta lainnya seperti perbankan dan pihak penjamin dalam hal ini adalah perusahaan asuransi. Dengan adanya dukungan dan sinergi yang positif dari berbagai pihak diharapkan dapat program ini akan dapat mengentaskan kemiskinan materiil yang terjadi di Kelurahan Malabro. 


\section{Bantuan beasiswa bagi anak anak miskin}

Program bantuan siswa miskin (BSM) menjadi alternatif program pengentasan kemiskinan materiil lainnya. Program ini diberikan kepada anak anak miskin yang memiliki ketidakmampuan untuk bersekolah. Program ini dapat membantu anak miskin yang ada di Kelurahan Malabro untuk memperoleh akses pelayanan pendidikan yang layak, mencegah putus sekolah, menarik anak miskin untuk kembali sekolah, membantu siswa memenuhi kebutuhan dalam kegiatan pembelajaran serta membantu kelancaran program sekolah. Melalui program ini diharapkan anak usia sekolah dari rumahtangga miskin di Kelurahan Malabro dapat terus bersekolah dan dimasa depan diharapkan dapat memutus mata rantai kemiskinan yang saat ini dihadapi orang tua mereka.

\section{Pelatihan motivasi kewirausahaan dan peningkatan daya saing usaha bagi pemuda karang taruna.}

Pemuda memiliki peran strategis bagi pertumbuhan ekonomi dan perkembangan inovasi. Untuk mengembangkan potensi para pemuda diperlukan upaya terintegrasi dan berkesinambungan. Para pemuda perlu dibekali dengan kemampuan kepemimpinan, pengetahuan, keterampilan serta pengalaman kewirausahaan. Melalui pelatihan kewirausahaan akan mendorong para pemuda memiliki jiwa kewirausahaan, memiliki kemampuan menciptakan lapangan pekerjaan yang akan memberdayakan orang orang disekitarnya, sehingga dapat meningkatkan pendapatan orang orang sekitarnya yang pada akhirnya dapat mengentaskan kemiskinan materiil.

Banyak pemuda karang taruna di Kelurahan Malabro yang mengalami masalah pengangguran. Para pemuda ini dapat diberdayakan secara ekonomi berbasis perikanan dengan memberikan pelatihan kewirausahaan, sehingga kedepannya para pemuda ini diharapkan dapat bekerja secara profesional, kreatif, mandiri, dan mampu bermitra secara independen dengan pihak lain, mampu menumbuh dan mengembangkan meningkatkan daya saing usaha yang akan dan sedang mereka jalankan.

\section{Pemberdayaan istri nelayan melalui pelatihan pengolahan hasil tangkapan ikan}

Untuk menopang pendapatan kepala rumahtangga, perlu diberdayakan SDM anggota keluarga lainnya terutama para istri nelayan. SDM para istri nelayan dapat diberdayakan dengan meningkatkan keterampilan dan pengetahuan mereka dalam mengolah hasil tangkapan laut yang ada melalui berbagai pelatihan yang didukung oleh Dinas Kelautan dan Perikanan Kota Bengkulu. Dengan adanya pelatihan peningkatan keterampilan dan pengetahuan para istri nelayan dalam mengolah hasil tangkapan laut akan dapat menciptakan mata pencaharian alternatif bagi keluarga nelayan sehingga dapat membantu meningkatkan pendapatan keluarga yang juga membantu mengentaskan kemiskinan materiil. 


\section{Pemanfaatan Lahan Pekarangan Rumah Melalui Pelatihan Hidroponik}

Lahan pekarangan memiliki potensi besar dalam mewujudkan ketahanan pangan berbasis keluarga. Lahan pekarangan dapat dimanfaatkan secara optimal, ditanami beragam jenis tanaman yang bisa memenuhi ketersediaan pangan bagi keluarga sekaligus sebagai sumber alternatif pendapatan bagi keluarga (rumahtangga). Namun keterbatasan lahan pekarangan yang dimiliki masyarakat Kelurahan Malabro menjadi kendala buat anggota keluarga nelayan untuk memanfaatkan secara optimal. Teknologi hidroponik dapat menjadi solusi dalam menfaatkan lahan pekarangan yang sempit secara optimal. Para anggota keluarga nelayan dapat diberikan pelatihan bagaimana cara bercocok tanam dengan menggunakan media tanam selain tanah seperti batu apung, kerikil, pasir, sabut, potongan kayu atau busa. dengan teknologi hidroponik fungsi tanah sebagai pendukung akar tanaman dan perantara larutan dapat digantikan dengan mengalirikan dan menambah nutris dan air dan oksigen melalui media. Dengan teknologi ini keterbatasan lahan pekarangan tidak lagi menjadi hambatan bagi anggota rumahtangga untuk membantu pendapatan kepala rumah tangga.

\section{Penutup}

Berdasarkan hasil temuan dilapangan maka dapat disimpulkan hasil penelitian sebagai berikut :

Dari 42 rumahtangga muslim yang diamati, dua diantaranya dikelompokan kedalam rumahtangga yang kaya materiil dikarenakan pendapatan yang mereka terima setiap bulannya berada diatas nilai nisab zakat penghasilannya. Sementara itu, 40 rumahtangga muslim lainnya termasuk rumahtangga yang tidak mampu memenuhi kebutuhan dasar karena pendapatan mereka berada dibawah nilai nisab zakat penghasilan, sehingga ke 40 rumahtangga muslim ini dikelompokan ke dalam kelompok rumahtangga miskin materil.

Tingginya angka kemiskinan materiil disebabkan beberapa hal yaitu

(a) sebagian besar profesi kepala rumahtangga adalah nelayan dengan tingkat produktivitas kerja mereka sangat tergantung kepada kondisi alam yang tidak menentu..

(b) keterbatasan peralatan untuk menangkap hasil laut baik secara teknologi maupun dalam hal ketersediaan kuantitas,, (c) para istri nelayan kebanyakan hanya berprofesi sebagai ibu rumahtangga yang tidak bisa membantu pendapatan suami.

Sedangkan kondisi aktual kemiskinan spritual di kelurahan malabro kecamatan teluk segara berdasarkan model cibest dari 42 rumahtangga muslim di Kelurahan Malabro yang diamati, keseluruhan rumahtangga merupakan rumahtangga yang mampu memenuhi kebutuhan spritual karena nilai SS > SV atau nilai SS > 3). Sehingga dengan demikian seluruh rumahtangga muslim yang diamati dikelompokan kedalam kelompok rumahtangga kaya spritual. Hal ini 
disebabkan latar belakang budaya narasumber dan masyarakat Kelurahan Malabro lainnya yang hampir 100\% berasal dari daerah minangkabau (Padang). Masyarakat minang adalah masyarakat arif dan kaya dengan kebudayaan dan filosofi dan lekat dengan nilai syariat islam, sehingga dalam menjalani kehidupan semuanya sesuai dengan kitab suci Al-Qur'an, ${ }^{65}$ sebagaimana falsafah hidup masyarakat minang "adat basandi syarak, syarak basandi Kitabullah". Artinya segala adat istiadat yang berlaku, segala aspek kehidupan yang dijalani harus berpedoman kepada Al-Qur'an. Falsafah hidup ini yang selalu diingat dan dijalani masyarakat minang dalam kondisi apapun termasuk dalam kondisi miskin materiil.

Kuadran CIBEST berdasarkan kondisi aktual kemiskinan materiil dan spritual di Kelurahan Malabro Kecamatan Teluk Segara Kota Bengkulu

\section{Kuadran CIBEST Berdasarkan Kombinasi Nilai Aktual MV dan SV Kelurahan Malabro Kecamatan Teluk Segara Kota Bengkulu}

\begin{tabular}{|l|l|l|}
\hline Skor Aktual & $\leq$ Nilai MV & $>$ Nilai MV \\
\hline$>$ nilai SV & Miskin materiil & Kaya materiil \\
& Kaya spritual (Pm) & Kaya spritual (W) \\
& 40 Rumah Tangga & 2 Rumah Tangga (0,474 atau \\
& $(0,9526$ atau 95,26\%) & $4,74 \%)$ \\
\hline$\leq$ nilai SV & Miskin materiil & kaya materiil \\
& miskin spritual $(\mathrm{Pa})$ & miskin spritual $(\mathrm{Ps})$ \\
& $0 \mathrm{rt}(0,0$ atau $0 \%)$ & $0 \mathrm{rt}(0,0$ atau $0 \%)$ \\
\hline
\end{tabular}

Indeks CIBEST dalam setiap kuadran menjelaskan 4,74\% rumahtangga muslim di Kelurahan Malabro hidup dalam kondisi sejahtera (kuadran I), 95,26\% dalam kondisi miskin materiil, (kuadran II), dan tidak ada rumahtangga yang diamati berada dalam kuadran III (miskin spritual) dan kuadran IV (miskin absolut).

Program Pengentasan Kemiskinan di Kelurahan Malabro Kecamata Teluk Segara Berdasarkan Model CIBEST

Kuadran II menjadi target utama program pengentasan kemiskinan dan pemberdayaan masyarakat. Desain program pengentasan kemiskinan di kuadran II harus ditekankan pada penguatan dari sisi materiil agar dapat meningkatkan kesejahteraan materiil rumahtangga, dan meningkatkan status rumahtangga dari mustahik menjadi muzzaki.

Beberapa program pengentasan kemiskinan dan pemberdayaan masyarakat yang dapat diusulkan sebagai berikut: Penyaluran dana zakat

\footnotetext{
${ }^{65}$ Wacana, Pandangan Hidup Orang Minang, googleweblight.com/ lite, diakses jumat 13 Oktober 2017, jam 04.55 WIB
} 
konsumtif, Penyaluran dana zakat produktif yang bersifat jangka panjang, bantuan modal kerja untuk rumahtangga miskin, bantuan beasiswa bagi anak anak miskin, Pelatihan motivasi kewirausahaan dan peningkatan daya saing usaha bagi pemuda karang taruna, pemberdayaan istri nelayan melalui pelatihan pengolahan hasil tangkapan ikan, dan pemanfaatan lahan pekarangan rumah melalui pelatihan hidroponik.

\section{Daftar Pustaka}

Abdullah Zaky Al Kaaf. 2002, Ekonomi dalam Perspektif Islam. Bandung, CV. Pustaka Setia

Al-Arif, Nur Rianto, 2010, Teori Makroekonomi Islam,Bandung, Alfabeta

Gus Arifin, 2016, Keutamaan Zakat, Infak, Sedekah, Jakarta: Gramedia

Bengkulu BPS, Provinsi Bengkulu Dalam Angka, dikutip dari Bengkulu. BPS.go.id, pada 30 Januari 2017, pukul 11.00 WIB

Eti Rochaety dan Ratih, 2007, Kamus Istilah Ekonomi, Cetakan ke dua, Jakarta, PT. Bumi Aksara

Etis Sunandi, dkk, Laporan Penelitian : "Analisis Statistika Deskriptif Dalam Pemetaan Kemiskinan Di Kota Bengkulu " (online), (repository.unib.ac.id, diakses 7 februari 2017, jam 15.53 WIB)

Handoko, Hani, 2003, Manajemen, Yogyakarta: BPFF

Huda, Nurul, 2015, Ekonomi Pembangunan Islam, Jakarta, Prenamedia Group

Irfan Syauqi Beik dan Laily Dwi Arsyianti, 20016, Ekonomi Pembangunan Syariah, Jakarta: Raja Grafindo Perada

Istiana Hermawati, Laporan Penelitian : Dampak Program Pengentasan Kemiskinan di Kabupaten Jayapura

Irfan Syauqi Beik, Konsep Dasar Model CIBEST, (Iqtishodia; Jurnal Ekonomi Islam Republika, Kamis 28 Mei 2015), diakses tanggal 11 September 2017

Kamus Besar Bahasa Indonesia, (online), (Http/kbbi.web.id/program, diakses 7 Februari 2017, jam 16.40 WIB)

Limbong, Bernhard, Ekonomi Kerakyatan dan Nasionalisme Ekonomi, Jakarta, Margaretha Pustaka

Mudrajat Kuncoro, 2003, Metode Riset Untuk Bisnis dan Ekonomi, Jakarta : Erlangga

Nurul Huda dkk, 2015, Ekonomi pembangunan Islam, Jakarta: Prenadagroup

Subandi, 2014, Ekonomi Pembangunan, Bandung, Afabeta

Solihin, Ismail, 2009, Pengantar Manajemen, Jakarta : Erlangga

Suryati . Pembangunan Sistem Informasi Pendataan Rakyat Miskin Untuk Program Beras Miskin (Raskin) Pada Desa Mantren Kecamatan Kebonagung Kabupaten Pacitan, Fakultas Teknologi Informatika Universitas Surakarta 